\title{
Assessing the stability of annual temperatures for different urban functional zones
}

\author{
Ranhao Sun ${ }^{a}$, Yihe Lü ${ }^{a}$, Liding Chen ${ }^{a, *}$, Liu Yang ${ }^{b}$, Ailian Chen ${ }^{a}$ \\ ${ }^{a}$ Research Center for Eco-Environmental Sciences, Chinese Academy of Sciences, Shuangqing Road 18, Haidian District, Beijing 100085, China \\ ${ }^{\mathrm{b}}$ China University of Mining and Technology, Xueyuan Road 11, Haidian District, Beijing 100083, China
}

\section{A R T I C L E I N F O}

\section{Article history:}

Received 25 October 2012

Received in revised form

31 March 2013

Accepted 2 April 2013

\section{Keywords:}

Urban heat island

Temperature stability

Landscape pattern

Landscape design

Urban planning

\begin{abstract}
A B S T R A C T
The urban functional zone (UFZ) is the basic unit of urban planning, which is defined as an area of similar social and economic functions. Despite the importance of UFZs, the stability of their annual temperature between winter and summer has seldom been investigated. With an understanding of the thermal impacts that planning decisions can have, it is essential to know how UFZs can be designed to regulate temperatures in the urban environment. 690 UFZs were identified using ALOS images in 2009 in Beijing. Land surface temperature (LST) was extracted from daytime Landsat TM (2002) and ASTER (2009) images. The regional LST variation of 31 district-sized sub-regions was correlated to the types of UFZs in the region and structural features of the region such as area, size, diversity, complexity and connectivity. Results showed that: (1) UFZ types, in order from highest to lowest LST variation, were commercial, campus, high density residential, water, recreational, low density residential, road, preservation, and agricultural zones; (2) the regional LST variation was positively correlated with the area of campus, commercial, high density residential, water, and road zones, but negatively correlated with the area of agricultural and low density residential zones; (3) increased connectivity and complexity decreased regional LST variations. The results indicated that the stability of annual temperatures was determined not only by the UFZ type and size but also by the connectivity and complexity. These results are clearly useful and essential pieces of information that can be applied in urban planning to improve climate adaptability.
\end{abstract}

Crown Copyright $\odot 2013$ Published by Elsevier Ltd. All rights reserved.

\section{Introduction}

6.3 billion people are projected to be living in cities by 2050 and the negative impact of this urbanization is an increasing concern for people worldwide [1]. One potential negative impact is that of urbanization on the local climate of urban areas, such as elevated temperatures from urban heat island, which can affect the energy use of buildings as well as the health of ecosystems and people [2-6].

Many of the patterns, processes, and thermal fluxes that differentiate the local climate of artificial and natural landscapes are addressed in the decisions that planners make [7]. Studies reveal that water bodies and wetlands serve as cooling surfaces by absorbing radiation through high thermal capacity and releasing water vapor that cools the ambient environment $[8,9]$. Vegetation

\footnotetext{
* Corresponding author. Tel.: +86 10 62943840; fax: +86 1062849102.

E-mail addresses: rhsun@rcees.ac.cn (R. Sun), lyh@rcees.ac.cn (Y. Lü), liding@ rcees.ac.cn (L. Chen), yang_1@126.com (L. Yang), cal-0601@163.com (A. Chen).
}

can decrease the near-surface air temperature by utilizing a relatively large proportion of the absorbed radiation in the evapotranspiration process and producing shade as well. The narrow arrangement of buildings along the city's streets forms urban canyons that inhibit the release of the reflected radiation to space from most of the three-dimensional urban surfaces. This radiation is ultimately absorbed by the building walls owing to their narrow arrangement and low thermal capacity, enhancing the UHI effect. Street trees and lawns have been used to mitigate UHI effects in big cities [10-13]. Green roofs and cool materials characterized by water retention or high solar reflectance values can also serve to cool the urban thermal environment [14-20]. The land surface temperature (LST) has been shown to be highly correlated with the near-surface air temperature [5,21]. The remotely sensed LST thus has thus often been used to assess the urban thermal environment due to its easy acquisition at a given moment and across broad areas [22,23]. Such studies attempt to reveal the effects and reasons of UHI by linking spatiotemporal variations in LST with land-cover and socio-economic indicators $[23,24]$. The proportion of landscape types, such as water, vegetated, and impervious areas, is found to 
Table 1

Weather conditions for each day of the acquisition of satellite images.

\begin{tabular}{|c|c|c|c|c|c|c|}
\hline Image type & Date & Precipitation (mm) & Atmospheric pressure (hPa) & Wind speed (m/s) & Air temperature $\left({ }^{\circ} \mathrm{C}\right)$ & Relative humidity (\%) \\
\hline \multirow[t]{4}{*}{ Landsat TM } & 2002.05 .22 & 0 & 1007.6 & 2.8 & 25.4 & 19 \\
\hline & 2002.07.09 & 0 & 998.3 & 3 & 27.5 & 64 \\
\hline & 2002.10 .13 & 0 & 1014.6 & 2 & 12.3 & 42 \\
\hline & 2002.11.14 & 0 & 1014.7 & 3 & 5 & 30 \\
\hline \multirow[t]{2}{*}{ ASTER } & 2009.03.06 & 0 & 1020.3 & 4 & 4.6 & 21 \\
\hline & 2009.08.08 & 0 & 1004.4 & 1.4 & 26.8 & 76 \\
\hline ALOS & 2009.04.21 & 0 & 1003.8 & 4.3 & 18.1 & 19 \\
\hline
\end{tabular}

have an essential impact on the spatial variations of the LST [11,25]. Recent studies reveal that the cooling effect of landscapes is correlated with the geometry and connectivity of landscape patches as well as the landscape types [9,26-28].

Increasingly, it has been recognized that urban landscape planning can be implemented to create additional energy savings and human comfort benefits [6,29-34]. However, few studies have been implemented to reveal how urban landscapes affect the land surface temperature difference between winter and summer. This difference is important if we evaluate the energy consumption for both heating and cooling a building over a year. Outdoor human comfort is also clearly affected by the temperature difference in winter and summer temperatures. Urban landscape planning includes a group of methods concerned with building locations, zoning, transportation, and how a town or city looks [35]. Urban functions are the largest concerns of landscape planning related directly to living, dwelling, education, industry, commerce, etc [36]. The urban functional zone (UFZ) is designated not only by its spectral characteristics but also by its social and economic functions in a city. The UFZ is usually organized by a specific function and therefore has a similar energy consumption and outdoor environment. Having information about the stability of annual temperatures for different UFZs enables urban planners and managers to rationalize the landscape planning sketches for an improvement of the urban thermal environment.

The urban thermal environment has attracted much attention in Beijing due to the city's rapid urban sprawl and population growth [37]. This study aims to: (1) assess the stability of annual temperatures for different UFZs inside the fifth ring-road of Beijing; and (2) quantify the relationship between regional LST variations and the UFZ structural features, including the area, size, diversity, complexity, and connectivity.

\section{Study area and methods}

\subsection{Study area}

Beijing is the capital of China, covering approximately $16,800 \mathrm{~km}^{2}$ of land, and is a major international metropolis that has experienced rapid development in recent decades. Beijing is characterized by a warm temperature zone and has a typical continental monsoon climate with four distinct seasons. Rapid urbanization and city expansion started in the late 1980s, resulting in significant UHI effects [38,39]. Previous studies have found that the mean daily temperature in urban areas is $4.6^{\circ}$ higher than the mean daily temperature in the suburbs [40]. The pattern of Beijing's development is a typical concentric expansion, showing a ring-shaped pattern with distance from the city center to the outskirts $[36,37]$. Our study area targeted the highly urbanized region inside the fifth ring-road of Beijing, with an area of $670 \mathrm{~km}^{2}$, which accounts for $4 \%$ of the total area of Beijing.

\subsection{UFZ and LST identification}

Three types of satellite images were used to identify the urban functional zones and land surface temperatures in this study. The weather conditions from the satellite images acquisitions were collected from the National Meteorological Information Center, China Meteorological Administration (Table 1). Two cloud-free Advanced Land Observing Satellite (ALOS) images were used to retrieve detailed information on UFZ types and structural features inside the fifth ring-road of Beijing. The ALOS data were acquired on April 21st, 2009, with 2.5-m spatial resolution in a panchromatic band and $10-\mathrm{m}$ spatial resolution in three visible and near-infrared bands. We identified the type and boundary of each UFZ manually according to the ALOS images. The 690 UFZs identified were classified into 10 major types based on our research objectivities (Table 2): high density residential zone (HDZ), low density residential zone (LDZ), campus zone (CPZ), industrial zone (IDZ), recreational zone (RAZ), commercial zone (CMZ), agricultural zone (AGZ), preservation zone (PVZ), road (ROD), and water (WTR) (Fig. 1).

Table 2

Classification of urban functional zones inside the fifth ring-road of Beijing.

\begin{tabular}{|c|c|c|c|}
\hline $\begin{array}{l}\text { Urban functional } \\
\text { zone }\end{array}$ & Code & $\begin{array}{l}\text { Areas } \\
\left(\mathrm{km}^{2}\right)\end{array}$ & Description \\
\hline $\begin{array}{l}\text { High density } \\
\text { residential } \\
\text { zone }\end{array}$ & HDZ & 252.76 & $\begin{array}{l}\text { 70-100\% impervious, construction material; } \\
\text { typically urban communities including } \\
\text { multiple family houses and high buildings, } \\
\text { and dense population in urban core areas. }\end{array}$ \\
\hline $\begin{array}{l}\text { Low density } \\
\text { residential } \\
\text { zone }\end{array}$ & LDZ & 30.08 & $\begin{array}{l}40-70 \% \text { impervious, construction material; } \\
\text { typically residential development including } \\
\text { sparse population and low buildings and } \\
\text { varying amounts of vegetation cover } \\
\text { commonly found in housing divisions. }\end{array}$ \\
\hline Campus zone & $\mathrm{CPZ}$ & 34.76 & $\begin{array}{l}\text { Areas for schools, colleges, institutes, } \\
\text { governments, hospitals, embassies, } \\
\text { military bases, etc. }\end{array}$ \\
\hline $\begin{array}{l}\text { Industrial } \\
\text { zone }\end{array}$ & IDZ & 81.52 & $\begin{array}{l}\text { Stations for passenger-transport of buses } \\
\text { and railways, airports, warehouses, } \\
\text { graveyards, etc. Factories for manufacturing, } \\
\text { electric power, food, gas, oil, water, etc. }\end{array}$ \\
\hline $\begin{array}{l}\text { Recreational } \\
\text { zone }\end{array}$ & RAZ & 59.28 & $\begin{array}{l}\text { Urban parks, golf courses, soccer fields, } \\
\text { and other recreation areas. }\end{array}$ \\
\hline $\begin{array}{l}\text { Commercial } \\
\text { zone }\end{array}$ & $\mathrm{CMZ}$ & 110.00 & $\begin{array}{l}\text { Offices for finance organizations and } \\
\text { headquarters, hotels, wholesale } \\
\text { markets, etc. }\end{array}$ \\
\hline $\begin{array}{l}\text { Agricultural } \\
\text { zone }\end{array}$ & AGZ & 19.99 & $\begin{array}{l}\text { Crops, gardens, and other herbaceous } \\
\text { vegetation. }\end{array}$ \\
\hline $\begin{array}{l}\text { Preservation } \\
\text { zone }\end{array}$ & PVZ & 17.96 & $\begin{array}{l}\text { Successional distribution of trees, shrubs, } \\
\text { and brushes, such as shelter-forest, } \\
\text { isolation belt, forest parks, etc. Natural } \\
\text { and manmade grassland. }\end{array}$ \\
\hline Road & ROD & 54.30 & Streets, roads, etc. \\
\hline Water & WTR & 8.31 & $\begin{array}{l}\text { All areas of open water, including rivers, } \\
\text { reservoirs, and lakes. }\end{array}$ \\
\hline
\end{tabular}




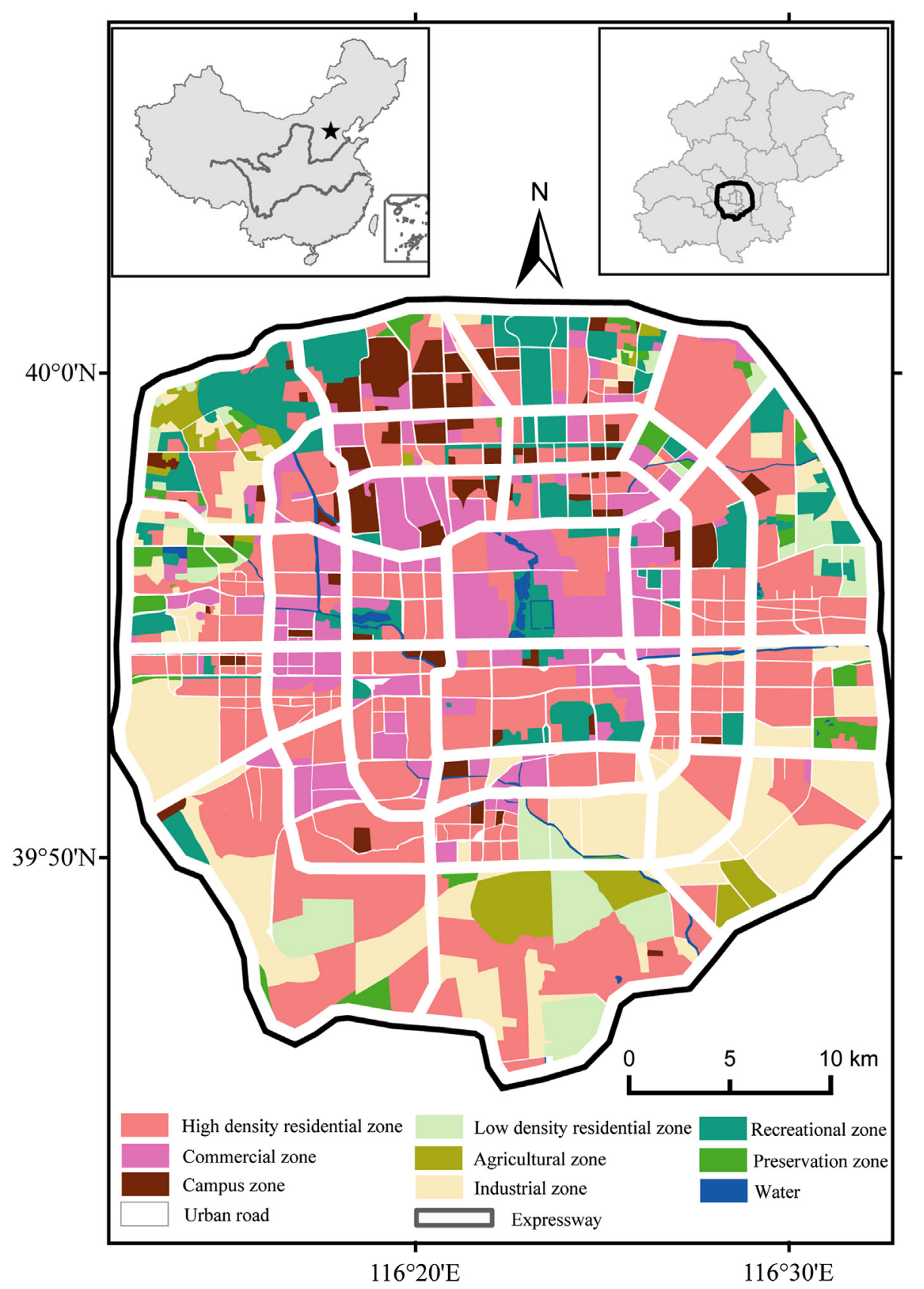

Fig. 1. Urban functional zone identified from the ALOS images.

The LST data were derived from the thermal infrared bands of the Advanced Spaceborne Thermal Emission and Reflection Radiometer (ASTER) images and Landsat Thematic Mapper (TM) images [21]. The ASTER images have 14 bands, including visible and nearinfrared bands (VNIR, 15-m spatial resolution), short wave infrared bands (SWIR, 30-m spatial resolution), and thermal infrared bands (TIR, 90-m spatial resolution). The Landsat TM images consist of 7 bands with a 30-m spatial resolution for Bands 1 to 5 and 7. The spatial resolution for Band 6 (thermal infrared) is $120 \mathrm{~m}$. The LST products are calculated by the temperature emissivity separation algorithm [5] and have been corrected for atmospheric emissivity by the Center for Earth Observation and Digital Earth, Chinese Academy of Sciences. The ASTER LST products were acquired on March 6th and August 8th, 2009, according to the cloud-free atmospheric conditions. The Landsat TM LST products were acquired on May 22nd, July 9th, October 13th, and November 14th, 2002. These LST data were re-sampled with a $10-\mathrm{m}$ resolution as well as the UFZ type map (Fig. 2). For all of the 690 UFZs, the LST variations between March and August in 2009 were significantly correlated to all of those in different months of 2002 (Table 3). Therefore, we use the LST variation in 2009 to represent the stability of annual temperatures for different UFZs. The following analysis was based mainly on the LST variations and UFZs in 2009.

\subsection{UFZ descriptors and statistical methods}

Urban spaces are usually cut into sub-regions by expressway networks, such as ring-roads, trunk roads, and several segments of national highways in Beijing. These expressways serve as barriers, fragmenting the urban spaces and possibly cutting off the thermal 

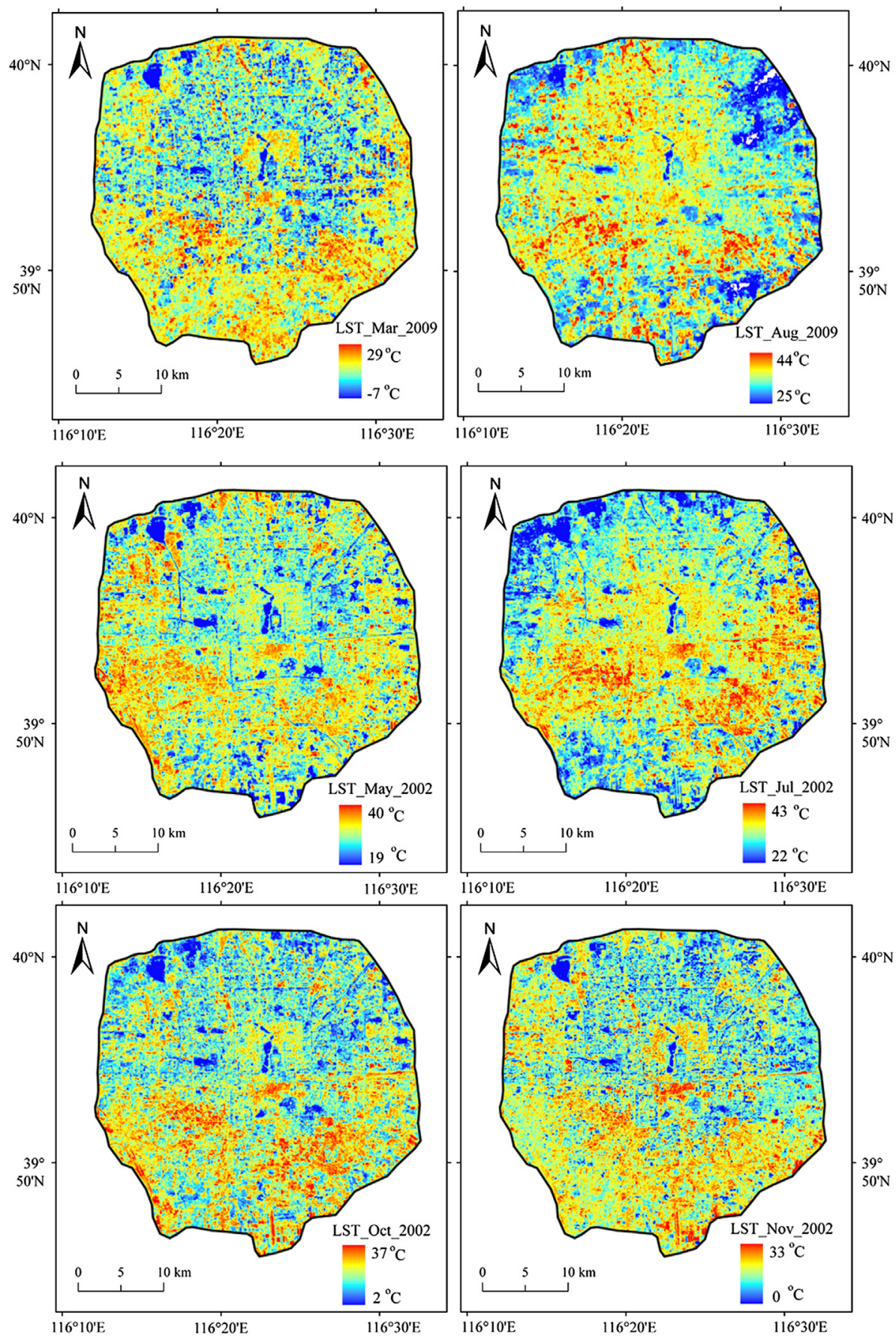

Fig. 2. Land surface temperature (LST) identified from ASTER and Landsat TM images.

Table 3

Correlation coefficients among the variations of land surface temperatures in different months (TV090308: LST difference between Mar 6 and Aug 8 in 2009 , TV020507: May 22 and Jul 9 in 2002, TV020710: Jul 9 and Oct 13 in 2002, TV021011: Oct 13 and Nov 14 in 2002, TV020510: May 22 and Oct 13 in 2002, TV020511: May 22 and Nov 14 in 2002, TV020711: Jul 9 and Nov 14 in 2002).

\begin{tabular}{|c|c|c|c|c|c|c|c|}
\hline & TV090308 & TV020507 & TV020710 & TV021011 & TV020510 & TV020511 & TV020711 \\
\hline TV090308 & 1.00 & & & & & & \\
\hline TV020710 & $0.55^{* *}$ & $-0.66^{* *}$ & 1.00 & & & & \\
\hline TV021011 & $0.32^{* *}$ & & $0.23^{* *}$ & 1.00 & & & \\
\hline TV020511 & $0.23^{* *}$ & $0.68^{* *}$ & & $0.62^{* *}$ & $0.89^{* *}$ & 1.00 & \\
\hline TV020711 & $0.50^{* *}$ & $-0.45^{* *}$ & $0.85^{* *}$ & $0.66^{* *}$ & & $0.26^{* *}$ & 1.00 \\
\hline
\end{tabular}

Note: significance level at ${ }^{* *} p<0.01$ (2-tailed). 
Table 4

List of the significant spatial metrics of urban functional zones at the landscape and class levels.

\begin{tabular}{|c|c|c|c|c|c|c|}
\hline \multirow{2}{*}{$\begin{array}{l}\text { Structural } \\
\text { feature }\end{array}$} & \multirow[t]{2}{*}{ Index } & \multirow[t]{2}{*}{ Full name } & \multirow[t]{2}{*}{ Meanings } & \multirow[t]{2}{*}{ Unit } & \multicolumn{2}{|l|}{ Formulae at landscape and class level } \\
\hline & & & & & Landscape & Class \\
\hline \multirow[t]{4}{*}{$\begin{array}{l}\text { Area and } \\
\text { size }\end{array}$} & PLAND & $\begin{array}{l}\text { Percent of } \\
\text { landscape }\end{array}$ & The percentage of each landscape class. & $\%$ & NA & PLAND $=P_{i}=\left(\sum_{j=1}^{n} a_{i j} / A\right)(100)$ \\
\hline & CLAND & $\begin{array}{l}\text { Core area } \\
\text { percent of } \\
\text { landscape }\end{array}$ & $\begin{array}{l}\text { The percentage of the total landscape } \\
\text { made up of the core area. }\end{array}$ & $\%$ & NA & CLAND $=\left(\sum_{j=1}^{n} a_{i j}^{c} / A\right)(100)$ \\
\hline & LPI & $\begin{array}{l}\text { Largest patch } \\
\text { index }\end{array}$ & The percent of the largest patch. & $\%$ & $\mathrm{LPI}=\left(\max \left(a_{i j}\right)_{j=1}^{n} / A\right)(100)$ & $\mathrm{LPI}=\left(\max \left(a_{i j}\right)_{j=1}^{n} / A\right)(100)$ \\
\hline & MPS & $\begin{array}{l}\text { Mean patch } \\
\text { size }\end{array}$ & Average patch size. & ha & $\mathrm{MPS}=A / N_{i}(1 / 10,000)$ & $\mathrm{MPS}=\left(\sum_{j=1}^{n} a_{i j} / n_{i}\right)(1 / 10,000)$ \\
\hline Complexity & AWMSI & $\begin{array}{l}\text { Area- } \\
\text { weighted } \\
\text { mean shape } \\
\text { index }\end{array}$ & $\begin{array}{l}\text { The sum of the perimeter of each patch } \\
\text { divided by the square root of the patch } \\
\text { area for each class (class level) or for all } \\
\text { patches (landscape level). AWMSI is equal } \\
\text { to } 1 \text { when all patches are circular or } \\
\text { square and it increases with greater } \\
\text { patch shape irregularity. }\end{array}$ & None & AWMSI $=\sum_{i=1}^{m} \sum_{j=1}^{n}\left[\left(p_{i j} / 2 \sqrt{\pi^{*} a_{i j}}\right)\left(a_{i j} / A\right)\right]$ & $\mathrm{AWMSI}=\sum_{j=1}^{n}\left[\left(p_{i j} / 2 \sqrt{\pi^{*} a_{i j}}\right)\left(a_{i j} / \sum_{j=1}^{n} a_{i j}\right)\right]$ \\
\hline Diversity & MSIDI & $\begin{array}{l}\text { Modified } \\
\text { Simpson's } \\
\text { diversity } \\
\text { index }\end{array}$ & $\begin{array}{l}\text { MSIDI equals zero when there is only one } \\
\text { patch in the landscape, and increases as } \\
\text { the number of patch types increases and } \\
\text { the area among patch types becomes } \\
\text { more equal. }\end{array}$ & None & $\mathrm{MSIDI}=-\ln \sum_{i=1}^{m} P_{i}^{2}$ & $\prod^{m}, \frac{m}{m}, m^{m}$ \\
\hline Connectivity & $\mathrm{IJI}$ & $\begin{array}{l}\text { Interspersion } \\
\text { and } \\
\text { Juxtaposition } \\
\text { Index }\end{array}$ & $\begin{array}{l}\text { IJI approaches zero when the distribution } \\
\text { of unique patch adjacencies becomes } \\
\text { uneven and } 100 \text { when all patch types } \\
\text { are equally adjacent. }\end{array}$ & $\%$ & $\begin{aligned} \mathrm{IJI}=( & \left(-\sum_{i=1} \sum_{k=i+1}\left[\left(e_{i k} / E\right) \ln \left(e_{i k} / E\right)\right]\right) / \\
& \left.\ln \left(1 / 2\left[m^{\prime}\left(m^{\prime}-1\right)\right]\right)\right)(100)\end{aligned}$ & $\mathrm{IJI}=\begin{aligned}\left(\left(-\sum_{k=1}\left[\left(e_{i k} / \sum_{k=1} e_{i k}\right) \ln \left(e_{i k} / \sum_{k=1} e_{i k}\right)\right]\right) /\right. \\
\left.\ln \left(m^{\prime}-1\right)\right)(100)\end{aligned}$ \\
\hline
\end{tabular}

Note: $i, k$ means $m$ or $m^{\prime}$ patch types; $j$ means $n$ patches; $a_{i j}$ means area $\left(\mathrm{m}^{2}\right)$ of patch $i j ; a_{i j}^{c}$ means core area $\left(\mathrm{m}^{2}\right)$ of patch $i j$ based on specified buffer width $(\mathrm{m}) ; A$ means total landscape area $\left(\mathrm{m}^{2}\right) ; e_{i k}$ means total length $(\mathrm{m})$ of edge

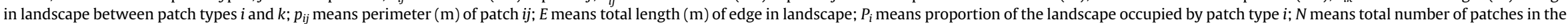
landscape. For further information, please refer toMcGarigal and Marks (1995) [41]. 
advection at a local scale. The study area was divided into 31 subregions by these expressways that were used as a regional file to average the LST variations under a GIS environment. The mean LST variation of each sub-region was assumed to be affected by structural features of the UFZs. The Spearman's rank correlation (Spearman's rho) was then used to examine the relationship between the mean regional LST variation and a group of selected structural features of UFZs in each sub-region. The initial descriptors of UFZ structural features were manifold and may be partially correlated with each other because they are derived from a few primary measurements from UFZ patches [41]. Based on the principles of landscape ecology and related studies [42], a small number of significant descriptors at the landscape and class level were selected to capture the major properties of a UFZ. These descriptors were used to describe some of the most important structural features, including the area and size, diversity, complexity, and connectivity (Table 4).

\section{Results}

\subsection{Spatial pattern of UFZ and LST}

The area of the UFZs ranged from 0.01 to $17.52 \mathrm{~km}^{2}$, with an average of $0.97 \mathrm{~km}^{2}$. The high and low density residential zones occupied $282.84 \mathrm{~km}^{2}$ (42.21\% of the study area), followed by the commercial $(16.42 \%)$, industrial $(12.17 \%)$, and recreational zones (8.85\%). As the political and cultural center of China, 5.19\% of the study area in Beijing was a campus zone for the purpose of university, college, school, hospital, or other institutions. Roads made up $8.1 \%$ of the entire research region, while agricultural and preservation zones occupied approximately $5.66 \%$. Water areas occupied only $1.24 \%$ of the region inside the fifth ring-road of Beijing. The percent of the core area was similar to that of the total area for different UFZs (Fig. 3). High residential zone had the highest values for LPI, PLAND, and CLAND, indicating that high residential zone was the main UFZ type in the study area with a high proportion of the largest patches. The relatively low area and patch size, but highest AWMSI and IJI in the road and water areas suggested high landscape complexity and connectivity. Low density residential zone occupied a relatively small area, but had the highest mean patch size. Preservation zone had a small area and patch size with relatively high connectivity.

There were obvious differences in the LST between March and August inside the fifth ring-road of Beijing. The LST decreased from the downtown area in August, whereas it increased in March (Fig. 4), indicating that the city center might be a "heat island" in August but a "cool island" in March. The highest values of LST variation were in the northwest region between the second and fourth ring-roads, followed by the southeast region inside the fourth ring-road. The lowest values of LST variation were mainly in the northeast and southeast parts of the study area.

Commercial, campus, and high density residential zones had high LSTs in August and the greatest LST variation between March and August. The average variation in LST for commercial, campus, and high density residential zones was generally higher than $21^{\circ} \mathrm{C}$. Correspondingly, the average LST variation for road, preservation, and agricultural zones was lower than $19{ }^{\circ} \mathrm{C}$. The average LST variation ranged from $19.48{ }^{\circ} \mathrm{C}$ to $19.97{ }^{\circ} \mathrm{C}$ for industrial, water, recreational, and low density residential zones. The UFZ types in order from highest to lowest LST variations were commercial, campus, high density residential, water, recreational, low density residential, road, preservation, and agricultural zones, as shown in Fig. 5.

\subsection{Correlations between regional LST variation and UFZ descriptors}

The Spearman's rho between the regional LST variation and the UFZ descriptors is reported in Table 5. At the landscape level, only LPI and MPS were correlated with the regional LST variation. At the class level, the UFZ area was characterized by PLAND, CLAND, LPI, and MPS. The Spearman's rho revealed a moderately positive relationship between the regional LST variation and the UFZ areas of campus, commercial, high density residential, water, and road zones. The regional LST variation was negatively correlated to the UFZ areas of low density residential and agricultural zones. The complexity and connectivity were obviously correlated to the LST variation of most UFZ types. Specifically, the LST variation was negatively correlated to AWMSI of the residential and commercial zones, and also to IJJ of water, low residential, recreational, and
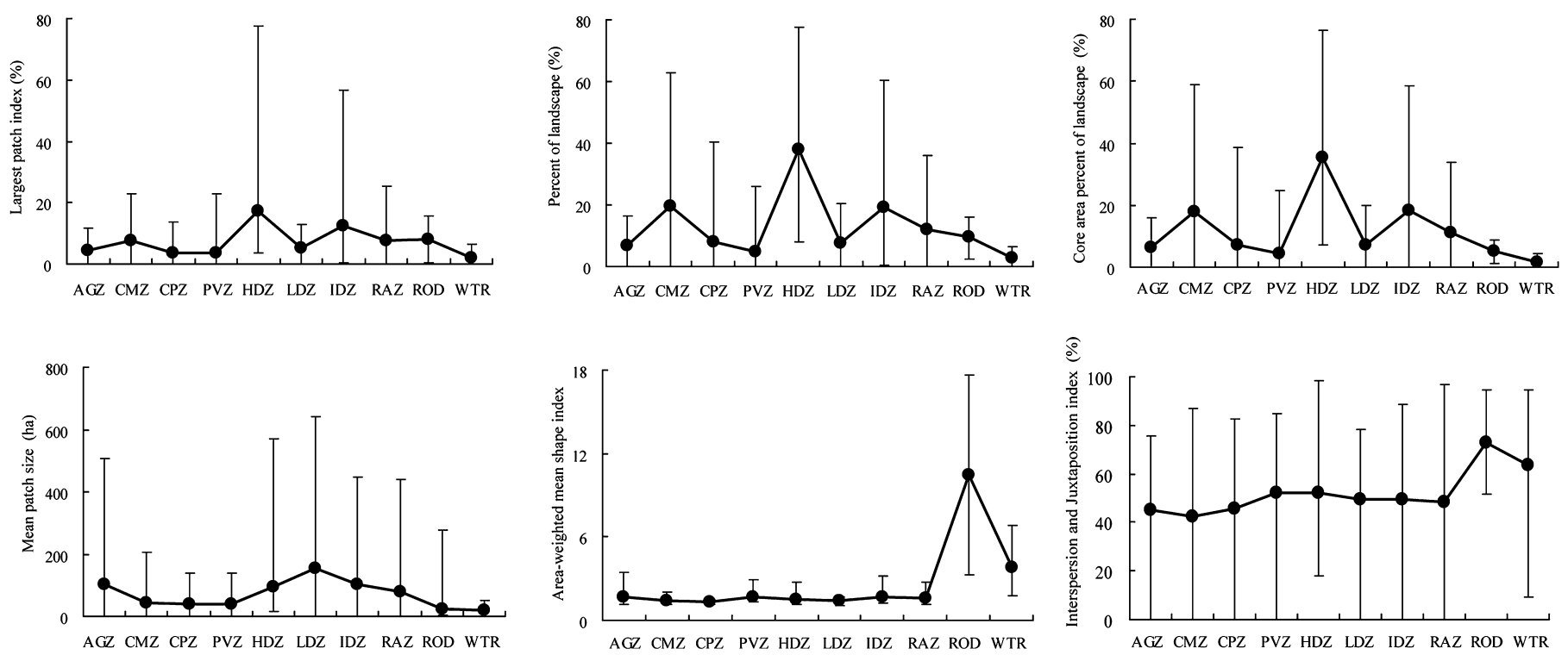

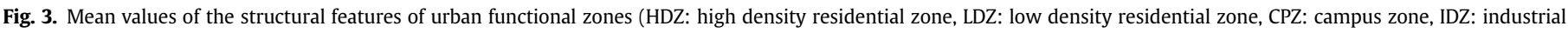
zone, RAZ: recreational zone, CMZ: commercial zone, AGZ: agricultural zone, PVZ: preservation zone, ROD: road, WTR: water). 

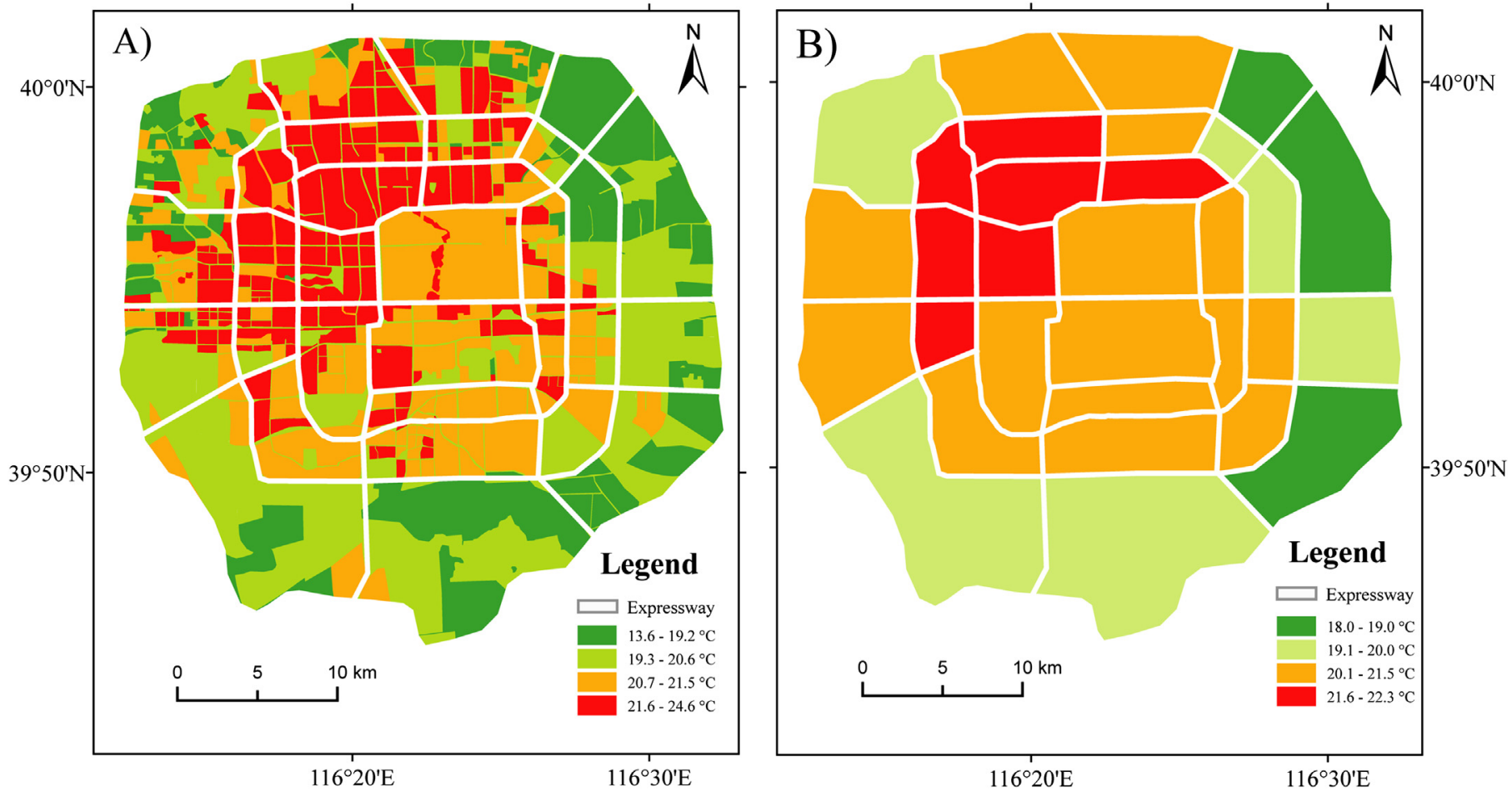

Fig. 4. Variation of land surface temperatures in urban functional zones (A) and sub-regions divided by urban expressways (B).

preservation zones. The results indicated that the regional LST variation may be mitigated by increased UFZ complexity and connectivity.

\section{Discussion}

\subsection{Major factors responsible for UFZ's temperature stability}

This study examined the intra-urban patterns of LST variation and revealed the relationship between the LST variation and structural features of UFZs. The similarity in the high LST variations of commercial, campus, and high density residential zones can be

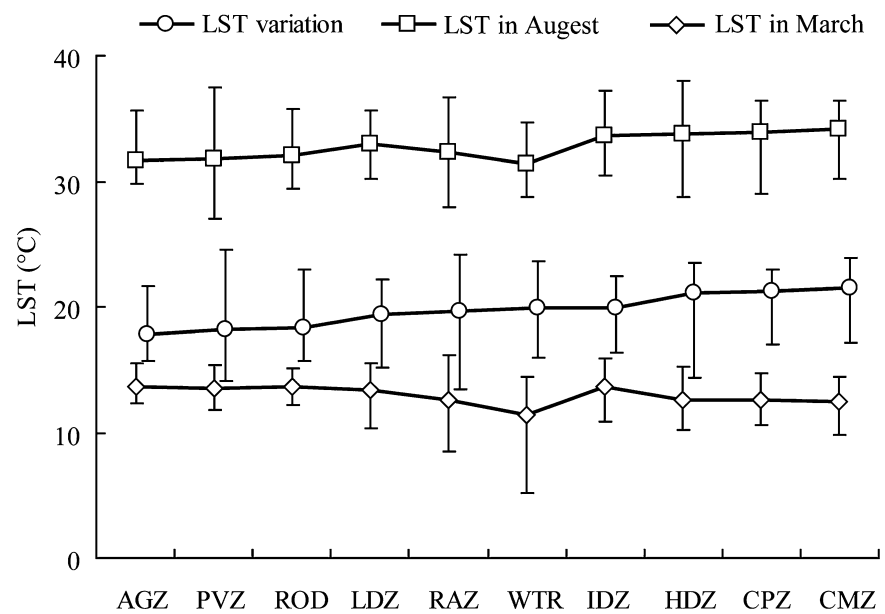

Fig. 5. Plots of mean land surface temperature (LST) and LST variation of urban functional zones. Urban functional zones are sorted by increasing average LST variation (HDZ: high density residential zone, LDZ: low density residential zone, CPZ: campus zone, IDZ: industrial zone, RAZ: recreational zone, CMZ: commercial zone, AGZ: agricultural zone, PVZ: preservation zone, ROD: road, WTR: water). explained by similar surface characteristics relating to the built materials and surrounding environment. These zones are typically characterized by a high proportion of built-up surface and usually have more impervious areas and flat concrete or metallic roofs. These surfaces are reported to have low albedo, emissivity, and thermal capacity $[43,44]$. Moderate LST variations were observed for industrial, recreational, and low density residential zones. These variations may be primarily to vegetation such as lawns or trees often found around the built structures in these UFZs, and the UFZs usually have more complexity or connectivity with surrounding landscapes. Water areas have the "thermostat effects" in comparison to surrounding building materials and serve as cool islands in urban regions during the summer [9,34]. However, water areas were observed to have moderate LST variation in this study. One explanation for this finding might be that water areas in Beijing tend to be covered by ice in March, and therefore increase reflection and decrease the absorption of solar radiation, enhancing the LST variation between summer and winter. Vegetation covers in low density residential and preservation zones as well as agricultural zones act as buffers between the ground and solar radiation, which helps to mitigate the LST variation between the summer and winter. The relatively low LST variation in the road zone may be produced by the vegetation cover and airflow around roads.

The regional LST variations are not only determined by the type and size of UFZs but are also impacted by their complexity and connectivity. The results indicate that the regional LST variations are correlated with the UFZ size alone for campus, road, and agricultural zones. The irregularity and connectivity increase the interfaces among different UFZs and can intensify the airflow due to the advection generated by the temperature gradient between "cool" and "heat" UFZs. Although the LST variation of road is relatively low, roads in urban areas have significant impacts on the production and transfer of heat because they can cut off other landscapes and decrease the connectivity among different landscapes. The largest and core patches of commercial and low 
Table 5

Correlation coefficients between the regional variation of land surface temperature and structural descriptors of urban functional zones.

\begin{tabular}{|c|c|c|c|c|c|c|c|c|c|c|c|}
\hline \multirow[t]{2}{*}{ Structural feature } & \multicolumn{10}{|c|}{ Class level } & \multirow[t]{2}{*}{ Landscape level } \\
\hline & $\mathrm{CPZ}$ & LDZ & IDZ & RAZ & $\mathrm{CMZ}$ & AGZ & HDZ & WTR & PVZ & ROD & \\
\hline PLAND & & & & & $0.54^{* *}$ & $-0.62^{* *}$ & $0.32^{*}$ & $0.58^{* *}$ & & & \\
\hline CLAND & $0.33^{*}$ & $-0.42^{*}$ & & & $0.58^{* *}$ & $-0.63^{* *}$ & & $0.67^{* *}$ & & $0.34^{*}$ & \\
\hline LPI & $0.32^{*}$ & $-0.41^{*}$ & & & $0.58^{* *}$ & $-0.64^{* *}$ & & $0.64^{* *}$ & & & $-0.32^{*}$ \\
\hline MPS & & & & & & $-0.46^{* *}$ & $0.38^{*}$ & $0.53^{* *}$ & & & $-0.54^{* *}$ \\
\hline AWMSI & & $-0.59^{* *}$ & & & $-0.38^{*}$ & & $-0.44^{* *}$ & & & & \\
\hline IJI & & $-0.47^{* *}$ & & $-0.41^{* *}$ & & & & $-0.51^{* *}$ & $-0.39^{*}$ & & \\
\hline MSIDI & & & & & & & & & & & \\
\hline
\end{tabular}

Note: Significance level at ${ }^{* *} p<0.01,{ }^{*} p<0.05$.

residential zones have more impacts on the temperature stability than the high density residential land. The recreational and preservation zones occupy a large proportion of vegetation covers in urban areas. Their connectivity has significantly negative correlations with the regional LST variation. The large water areas intensify the regional LST variation, but the connectivity of water areas can mitigate the regional LST variation. The low density residential land is the only UFZ type impacted by the structural features involving the area, complexity, and connectivity.

\subsection{Implications for urban planning and management}

Some implications may be useful for further research and management in urban areas. First, our study shows that the largest LST variation does not lie in the city center but in the northwest part of our study area. This result provides specific targets for urban managers and planners in developing rational strategies to improve urban thermal environments. Second, the temperature stability is significantly different among the UFZ types. The large LST variations caused by the intra-urban landscape heterogeneity are consistent with the findings in other areas $[23,25,26]$. Commercial, campus, industrial, and high density residential zones significantly intensify the LST variation and, thus, have relatively low temperature stability. It is possible to attain a low regional LST variation by planning different UFZs in a reasonable configuration. Last, the temperature stability is also affected by the UFZ's complexity and connectivity. Corridors of preservation and water areas are valuable for improving the built and outdoor environments. In addition, more irregular designs in UFZs, such as commercial and residential zones, might provide additional landscape benefits in dense urban areas.

\subsection{Limitations and improvements of this study}

While this study reveals the effects of UFZs on the annual temperature for different UFZs in the Beijing metropolitan area, there may be some limitations. The conclusions of this study are based on the assumption that urban expressways cut off most of the thermal exchange between sub-regions. The correlations between LST variation and UFZ structural descriptors are quantified using sub-regions as the observational unit. However, the mean temperature of a sub-region may be impacted by its surrounding expressways and other sub-regions, which may impact the accuracy of our study. Another limitation is that we did not quantify the detailed composition of land covers such as impervious and vegetation areas in each UFZ. Land covers are significant determinants of the LST and near-surface air temperature. It would be desirable to quantify the proportion of impervious and vegetated areas in each UFZ to represent the built and outdoor environments more accurately in a further study. We also note that some climatic and environmental factors, such as wind, snow, and cloud, have not been considered in this study but may influence the variations of the LST and near-surface air temperature $[44,45]$. There is a large gap between the surface temperatures in our data set and the air temperatures that the citizens ultimately feel. Further in situ measurement of air temperature and microclimatic factors would be useful for evaluating the outdoor environment and human comfort. Lastly, the acquisition of remote sensing images is constrained to the time of day as well as the atmospheric conditions. We cannot collect enough images to capture the LST variations in all months of a year. A more comprehensive understanding of the temperature stability for different UFZs would be possible if we could obtain more remote sensing images at multiple times with varying LST and land cover characteristics. The new sharpening methods could help us obtain high-resolution urban thermal data in a further study [46]. We also note that a rigorous screening process should be implemented to determine which surface temperature pixels are suitable to correlate remotely sensed surface temperatures with near-surface air temperatures.

\section{Conclusions}

This study presents the spatial distribution of temperature stability inside the fifth ring-road of Beijing using multiple remote sensing images, and quantifies the correlations between temperature stability and the structural features of UFZs. The results indicate that not only do the type and size significantly affect the temperature stability, but the complexity and connectivity of UFZs also matter. Although this study can be enhanced in designing more rational observational units and supplementing more spatial information on LST and land cover, it expands our scientific understanding of the effects of UFZs on the temperature stability. This study could provide useful implications for urban planners and managers using microclimatic landscape design to create thermal comfort and energy efficiency.

\section{Acknowledgments}

The work was financed by the Natural Science Foundation of China (41230633) and the Innovation Project of State Key Laboratory of Urban and Regional Ecology of China. The authors wish to thank the anonymous referees for their constructive comments that improved substantially the manuscript.

\section{References}

[1] United Nations. World urbanization prospects - the 2009 revision 2009. Working paper no. ESA/P/WP 215.

[2] Grimm NB, Foster D, Groffman P, Grove JM, Hopkinson CS, Nadelhoffer KJ et al. The changing landscape: ecosystem responses to urbanization and pollution across climatic and societal gradients. Front Ecol Environ 2008;6: 264-72.

[3] Shen WJ, Wu JG, Grimm NB, Hope D. Effects of urbanization-induced environmental changes on ecosystem functioning in the phoenix metropolitan region, USA. Ecosystems 2008;11:138-55. 
[4] Buyantuyev A, Wu JG. Urbanization diversifies land surface phenology in arid environments: interactions among vegetation, climatic variation, and land use pattern in the Phoenix metropolitan region, USA. Landsc Urban Plan 2012;105:149-59.

[5] Weng Q. Thermal infrared remote sensing for urban climate and environmental studies: methods, applications, and trends. ISPRS J Photogramm Remote Sens 2009;64:335-44.

[6] Vanos JK, Warland JS, Gillespie TJ, Kenny NA. Review of the physiology of human thermal comfort while exercising in urban landscapes and implications for bioclimatic design. Int J Biometeorol 2010;54:319-34.

[7] Comarazamy DE, González JE, Luvall JC, Rickman DL. Climate impacts of land cover and land use changes in tropical islands under conditions of global climate change. J Clim 2012. http://dx.doi.org/10.1175/ICLI-D-12-00087.1.

[8] Chang CR, Li MH, Chang SD. A preliminary study on the local cool-island intensity of Taipei city parks. Landsc Urban Plan 2007;80:386-95.

[9] Cao X, Onishi A, Chen J, Imura H. Quantifying the cool island intensity of urban parks using ASTER and IKONOS data. Landsc Urban Plan 2010;96:224-31.

[10] Shashua-Bar L, Hoffman ME. Vegetation as a climatic component in the design of an urban street: an empirical model for predicting the cooling effect of urban green areas with trees. Energy Build 2000;31:221-35.

[11] Li JX, Song CH, Cao L, Zhu FG, Meng XL, Wu JG. Impacts of landscape structure on surface urban heat islands: a case study of Shanghai, China. Remote Sens Environ 2011;115:3249-63.

[12] Susca T, Gaffin SR, Dell'Osso GR. Positive effects of vegetation: urban heat island and green roofs. Environ Pollut 2011;159:2119-26.

[13] Park M, Hagishima A, Tanimoto J, Narita K. Effect of urban vegetation on outdoor thermal environment: field measurement at a scale model site. Build Environ 2012;56:38-46.

[14] Domingueza A, Kleissla J, Luvall JC. Effects of solar photovoltaic panels on roof heat transfer. Sol Energy 2011;85:2244-55.

[15] Synnefa A, Dandou A, Santamouris M, Tombrou M, Soulakellis N. On the use of cool materials as a heat island mitigation strategy. J Appl Meteorol Climatol 2008;47:2846-56.

[16] Nakayama T, Fujita T. Cooling effect of water-holding pavements made of new materials on water and heat budgets in urban areas. Landsc Urban Plan 2010;96:57-67.

[17] He JA. A design supporting simulation system for predicting and evaluating the cool microclimate creating effect of passive evaporative cooling walls. Build Environ 2011;46:584-96.

[18] Santamouris M, Gaitani N, Spanou A, Saliari M, Giannopoulou K, Vasilakopoulou $\mathrm{K}$, et al. Using cool paving materials to improve microclimate of urban areas: design realization and results of the flisvos project. Build Environ 2012;53:128-36.

[19] Alexandri E, Jones P. Temperature decreases in an urban canyon due to green walls and green roofs in diverse climates. Build Environ 2008;43:480-93.

[20] Clark C, Adriaens P, Talbot FB. Green roof valuation: a probabilistic economic analysis of environmental benefits. Environ Sci Technol 2008;42:2155-61.

[21] Nichol JE, Wong MS. Spatial variability of air temperature and appropriate resolution for satellite-derived air temperature estimation. Int J Remote Sens 2008;29:7213-23.

[22] Lo CP, Quattrochi DA, Luvall JC. Application of high-resolution thermal infrared remote sensing and GIS to assess the urban heat island effect. Int J Remote Sens 1997;18:287-304.

[23] Buyantuyev A, Wu JG. Urban heat islands and landscape heterogeneity: linking spatiotemporal variations in surface temperatures to land-cover and socioeconomic patterns. Landsc Ecol 2010;25:17-33.
[24] Jenerette GD, Harlan SL, Brazel A, Jones N, Larsen L, Stefanov WL. Regional relationships between surface temperature, vegetation, and human settlement in a rapidly urbanizing ecosystem. Landsc Ecol 2007;22:353-65.

[25] Liu H, Weng QH. Seasonal variations in the relationship between landscape pattern and land surface temperature in Indianapolis. USA Environ Monit Assess 2008;144:199-219.

[26] Zhou WQ Huang GL, Cadenasso ML. Does spatial configuration matter? Understanding the effects of land cover pattern on land surface temperature in urban landscapes. Landsc Urban Plan 2011;102:54-63.

[27] Sun RH, Chen AL, Chen LD, Lü YH. Cooling effects of wetlands in an urban region: the case of Beijing. Ecol Indic 2012;20:57-64.

[28] Mackey CW, Lee XH, Smith RB. Remotely sensing the cooling effects of city scale efforts to reduce urban heat island. Build Environ 2012;49:348-58.

[29] Givoni B. Impact of planted areas on urban environmental quality: a review. Atmos Environ 1991;25:289-99.

[30] Makhzoumi JM. Landscape ecology as a foundation for landscape architecture: application in Malta. Landsc Urban Plan 2000;50:167-77.

[31] Giridharan R, Lau SSY, Ganesan S, Givoni B. Urban design factors influencing heat island intensity in high-rise high-density environments of Hong Kong. Build Environ 2007;42:3669-84.

[32] Bowler DE, Buyung-Ali L, Knight TM, Pullin AS. Urban greening to cool towns and cities: a systematic review of the empirical evidence. Landsc Urban Plan 2010;97:147-55.

[33] Wu JG. Urban sustainability: an inevitable goal of landscape research. Landsc Ecol 2010;25:1-4

[34] Sun RH, Chen LD. How can urban water bodies be designed for climate adaptation? Landsc Urban Plan 2012;105:27-33.

[35] Simonds JO. Landscape architecture: a manual of site planning and design. New York: McGraw-Hill Professional; 2007.

[36] Tian GJ, Wu JG, Yang ZF. Spatial pattern of urban functions in the Beijing metropolitan region. Habitat Int 2010;34:249-55.

[37] Xiao RB, Weng QH, Ouyang ZY, Li WF, Schienke EW, Zhang ZM. Land surface temperature variation and major factors in Beijing, China. Photogramm Eng Rem S 2008;74:451-61.

[38] Liu W, Ji C, Zhong J, Jiang X, Zheng Z. Temporal characteristics of the Beijing urban heat island. Theor Appl Climatol 2007;87:213-21.

[39] Ren GY, Chu ZY, Chen ZH, Ren YY. Implications of temporal change in urban heat island intensity observed at Beijing and Wuhan stations. Geophys Res Lett 2007;34:L05711.

[40] Song YL, Zhang SY. The study on heat island effect in Beijing during last 40 years. Chin J Eco-agriculture 2003;11:126-9 [in Chinese].

[41] McGarigal K, Marks BJ. FRAGSTATS: spatial pattern analysis program for quantifying landscape structure. General technical report. Portland: U.S Department of Agriculture, Forest Service, Pacific Northwest Research Station; 1995.

[42] Yang XJ. An assessment of landscape characteristics affecting estuarine nitrogen loading in an urban watershed. J Environ Manage 2012;94:50-60.

[43] Taha $\mathrm{H}$. Urban climates and heat islands: albedo, evapotranspiration, and anthropogenic heat. Energy Build 1997;25:99-103.

[44] Malevich SB, Klink K. Relationships between snow and the wintertime Minneapolis urban heat island. J Appl Meteorol Climatol 2011;50:1884-94.

[45] Comarazamy DE, González JE, Luvall JC, Rickman DL, Mulero PJ. A land-atmospheric interaction study in the coastal tropical city of San Juan, Puerto Rico. Earth Interact 2010;14:1-24.

[46] Dominguez A, Kleissl J, Luvall JC, Rickman DL. High-resolution urban thermal sharpener (HUTS). Remote Sens Environ 2011;115:1772-80. 